\title{
Unusual case report of an adenomatoid odontogenic tumor in the mandible: 3-years of follow-up
}

Relato de caso incomum de tumor odontogênico adenomatoide em mandíbula: 3 anos de acompanhamento Reporte de caso infrecuente de tumor odontogénico adenomatoide en mandíbula: seguimiento a 3 años Jéssica Daniela ANDREIS ${ }^{1}$ Dayane Jaqueline $\mathbf{G R O S S}^{\mathbf{2}}$ Amanda Regina FISCHBORN ${ }^{1}$

${ }^{1}$ PhD Student, Department of Dentistry, State University of Ponta Grossa (UEPG), 84030-900 Ponta Grossa - PR, Brazil ${ }^{2}$ Oral and Maxillofacial Surgery Resident, Regional University Hospital of Campos Gerais (HU), 84031-510 Ponta Grossa - PR, Brazil. ${ }^{3}$ Adjunct Professor, Department of Dentistry, Unicesumar University, 84036-350 Ponta Grossa - PR, Brazil

${ }^{4}$ Adjunct Professor, Department of Dentistry, State University of Ponta Grossa (UEPG), 84030-900 Ponta Grossa - PR, Brazil ${ }^{5}$ Laboratory of Pathology, Sample Diagnóstico, 84052-460 Ponta Grossa - PR, Brazil

\section{Abstract}

This case report showed an AOT in a 12-year-old female patient referred for orthodontic-surgical of both impacted right mandibular canine and lateral incisor. Cone beam computed tomography revealed a well-defined mixed hyperdense/hypodense lesion, involving the crown of the mandibular lateral incisor. The surgery consisted in surgical exposure of the mandibular right canine and lateral incisor, bonding of the lateral incisor for orthodontic traction and curettage of the mandibular lesion. Histopathological examination revealed several columnar epithelial cells with minimal stromal connective tissue, lobular pattern and rosettes and duct-like structures, confirming the diagnosis of AOT. After, the patient was referred for orthodontic traction of the impacted teeth. At 1 and 3-year postoperatively, follow-ups examinations showed extensive bone repair, resolution of the tooth-retention and absence of recurrence. Although AOT is an uncommon lesion in the mandible, it should be considered in the differential diagnosis of the mixed profile lesions in this region.

Descriptors: Odontogenic Tumors; Mandible; Cone-Beam Computed Tomography; Diagnosis.

\section{Resumo}

Este relato de caso mostrou um TOA em uma paciente de 12 anos, do sexo feminino, encaminhada para cirurgia ortodônticocirúrgica de canino inferior direito e incisivo lateral retidos. A tomografia computadorizada de feixe cônico revelou uma lesão mista hiperdensa / hipodensa bem definida, envolvendo a coroa do incisivo lateral inferior. A cirurgia consistiu na exposição cirúrgica do canino inferior direito e incisivo lateral, colagem do incisivo lateral para tração ortodôntica e curetagem da lesão mandibular. O exame histopatológico revelou várias células epiteliais colunares com pouco tecido conjuntivo estromal, padrão lobular com rosetas e estruturas semelhantes a ductos, confirmando o diagnóstico de TOA. Em seguida, a paciente foi encaminhada para tração ortodôntica dos dentes impactados. No pós-operatório de 1 e 3 anos, os exames de acompanhamento mostraram extenso reparo ósseo, resolução da retenção dentária e ausência de recorrência. Embora o TOA seja uma lesão incomum na mandíbula, deve ser considerada no diagnóstico diferencial das lesões de perfil misto nesta região. Descritores: Tumores Odontogênicos; Mandíbula; Tomografia Computadorizada de Feixe Cônico; Diagnóstico.

\section{Resumen}

Este caso clínico mostró un TOA en una paciente de 12 años remitida para cirugía ortodóncica-quirúrgica de canino inferior derecho e incisivo lateral retenidos. La tomografía computarizada de haz cónico reveló una lesión mixta hiperdensa / hipodensa bien definida, que involucraba la corona del incisivo lateral inferior. La cirugía consistió en la exposición quirúrgica del canino inferior derecho y el incisivo lateral, unión del incisivo lateral para la tracción ortodóncica y legrado de la lesión mandibular. El examen histopatológico reveló varias células epiteliales columnares con poco tejido conjuntivo estromal, patrón lobulillar con rosetas y estructuras ductiles, lo que confirma el diagnóstico de TOA. Luego, el paciente fue derivado para tracción ortodóncica de los dientes impactados. En el período posoperatorio de 1 y 3 años, los exámenes de seguimiento mostraron una reparación ósea extensa, resolución de la retención dentaria y ausencia de recurrencia. Aunque la TOA es una lesión infrecuente en la mandíbula, debe considerarse en el diagnóstico diferencial de lesiones de perfil mixto en esta región.

Descriptores: Tumores Odontogénicos; Mandíbula; Tomografía Computarizada de Haz Cónico; Diagnóstico.

\section{INTRODUCTION}

Adenomatoid odontogenic tumor (AOT) is an uncommon benign, noninvasive and painless odontogenic tumor, comprising of 3-7\% of all odontogenic tumors, with variable radiographic and histological features. AOT was first named in 1969 by Philipsen and Birn and this terminology was adopted in 1971 by the first edition of the World Health Organization ${ }^{1}$.

AOT is usually detected in routine radiographic exams, mainly during the second decade of life, in young individuals with a female predominance $^{2-4}$. Two-third of AOTs are welldefined mixed hyperdense/hypodense lesions, with a strong predilection by the anterior maxilla and represent more than $50 \%$ of the cases.
Clinically, it presents as an asymptomatic bone expansion ${ }^{3,5}$.

There are three clinicopathological variants: intraosseus follicular, intraosseus extrafollicular and peripheral. However, all variants have the same microscopical appearance. The follicular type is a central intraosseus lesion associated with an impacted tooth, while extrafollicular intraosseus AOT has no relation with an unerupted tooth. The peripheral variant seems to be associated to soft tissue ${ }^{6-9}$.

Histological features of AOT include lobular pattern with rosettes and duct-like structures constituted by columnar epithelial 
cells and the cribriform/trabecular aspect with cords of basaloid cells. In addition, varying degrees of inductive changes in the connective tissue have been observed ${ }^{3,7}$. Commonly, these structures are surrounded by a well-developed connective tissue capsule. It may present as a solid mass, a single large cystic space, or as numerous small cystic spaces ${ }^{10-12}$. Differential diagnosis regarding to AOT is extensive and includes dentigerous and lateral periodontal cysts, ameloblastoma and calcifying epithelial odontogenic tumor ${ }^{13-15}$

The treatment of AOT presents a conservative pattern and consists in enucleation/curettage with rare relapses ${ }^{16,17}$. The objective of this study was to report an unusual case of mandibular AOT associated with the crown of an impacted lateral incisor in a 12-year-old girl, treated with curettage and orthodontic traction of the tooth without recurrence of the lesion in a 3-year follow-up. CLINICAL CASE

A 12-year-old caucasian female patient was referred to surgical orthodontic traction of right mandibular canine and lateral incisor, both impacted in the mandible. Panoramic radiograph revealed bone retention of these teeth with a radiolucent unilocular lesion involving the crown of right mandibular lateral incisor (Figure 1).

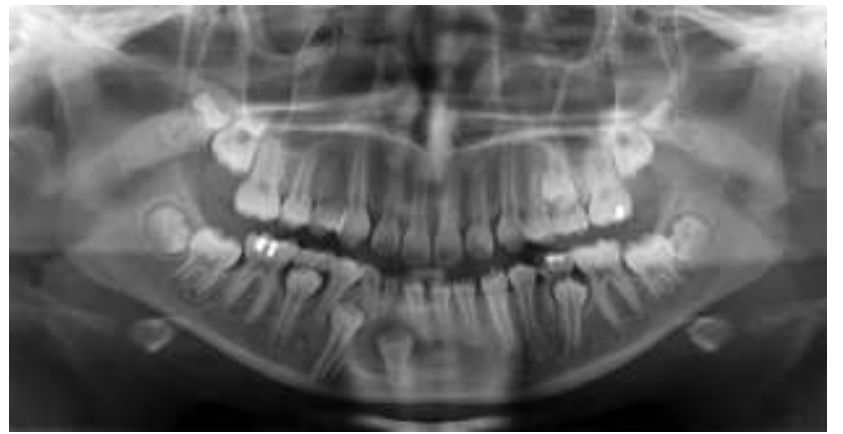

Figure 1: Initial panoramic radiograph showing radiolucent unilocular lesion involving the crown of right mandibular lateral incisor.

Intraoral examination showed the absence of right mandibular canine and lateral incisor and expansion of the vestibular and palatine cortical bone of the mandible, without any signs of inflammation (Figure 2).

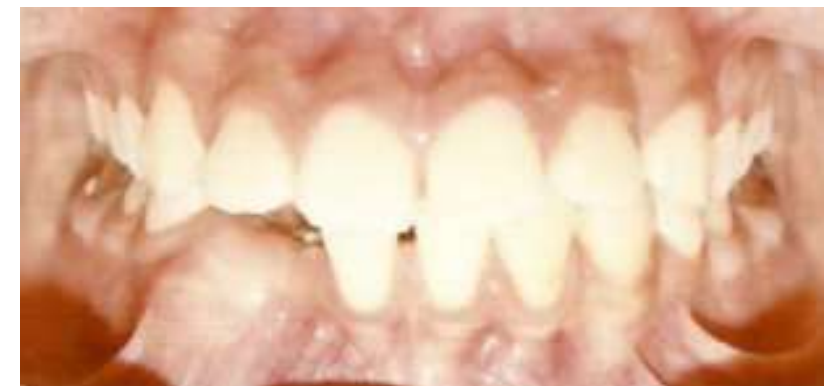

Figure 2: Initial intraoral aspect with absence of right mandibular canine and lateral incisor, associated to expansion of the vestibular and palatine cortical bone of this region, without any signs of inflammation.
Based on these findings, the imaging diagnosis was related to dentigerous cyst or similar lesion, such as keratocystic odontogenic tumor or ameloblastoma. A cone beam computed tomography (CBCT) demonstrated a thin buccal cortical plate due to expansion of the lesion, a resorption of the lingual cortical plate and radio-opaque flakes inside the lesion. Moreover, no dental resorption was observed (Figure 3).

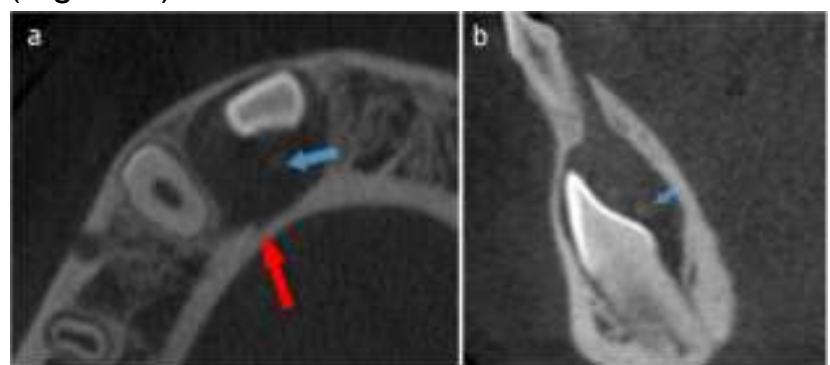

Figure 3: Initial tomographic aspect. The axial (a) and sagital (b) slices of the CBCT revealed radio-opaque flakes inside the lesion (blue arrows) and a resorption of the lingual cortical bone (red arrow).

Based on CBCT sections, the main diagnoses changed to a mixed profile lesion and included AOT, calcifying epithelial odontogenic tumor and calcifying odontogenic cyst $^{18,19,20,21}$. Legal guardians signed informed consent regarding publishing their data and photographs. Therefore, the main presumptive diagnosis was AOT with follicular pattern, considering the age of patient and the absence of dental resorption. In the sequence, the surgery was performed under local anesthesia and consisted in surgical exposure of the right mandibular canine, bonding of the lateral incisor for orthodontic traction and curettage of the mandibular lesion. The macroscopic appearance of the lesion consisted in a solid-encapsulated mass with well-defined limits. After the biopsy procedure, fragments were fixed for 24 hours in 10\% buffered formalin and then embedded in paraffin. Serial sections of $5 \mu \mathrm{m}$ thick were stained with hematoxylin and eosin. Histopathologic examination revealed several columnar epithelial cells with minimal stromal connective tissue, lobular pattern and rosettes and duct-like structures, confirming the diagnosis of AOT (Figure 4).

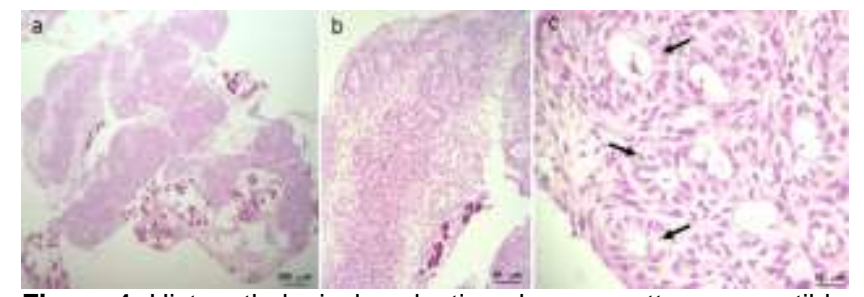

Figure 4: Histopathological evaluation shows a pattern compatible with TOA. Observe the presence of epithelial cells with minimal stromal connective tissue, lobular pattern and typical rosettes and duct-like structures (arrows). 
After one year of follow-up, the panoramic exam showed partial bone healing in the operated area, the right mandibular canine had erupted and the lateral incisor was still under orthodontic traction (Figure 5).

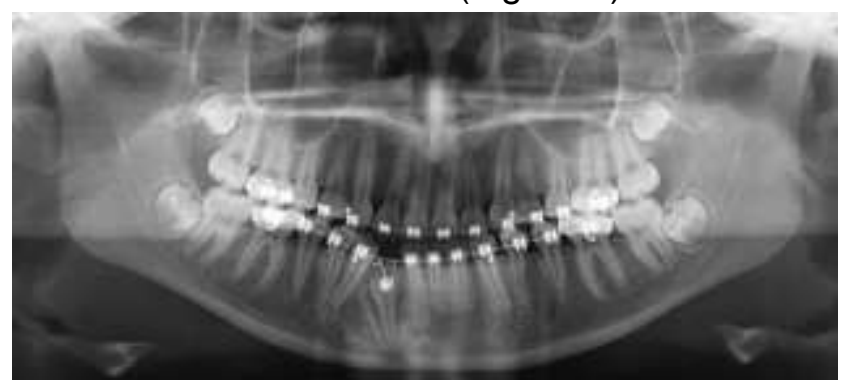

Figure 5: Panoramic radiograph of the 1-year follow-up. Observe reveal partial bone healing and complete eruption of right mandibular canine while the presence of right mandibular lateral incisor under orthodontic traction.

A new surgical procedure was performed to expose the crown of the lateral incisor and to optimize the orthodontic traction. After this procedure, the orthodontic treatment was carried out without complications. During the three-year follow-up period, the orthodontic treatment was concluded, with both right mandibular canine and lateral incisor in occlusion. In addition, the panoramic radiograph showed complete bone repair with no signs of relapse, as illustrated in the figure 6 .

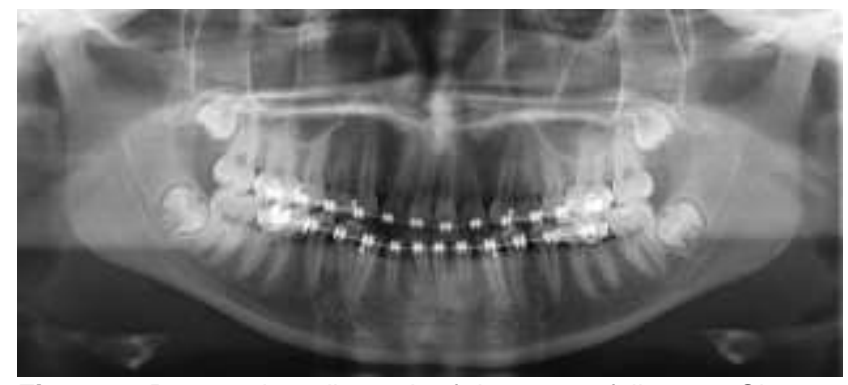

Figure 6: Panoramic radiograph of the 3-year follow-up. Observe the presence of right mandibular canine and lateral incisor in occlusion with complete bone healing and no signs of recurrence.

DISCUSSION

AOT is considered a benign and painless odontogenic tumor, arising from the enamel organ or dental lamina. This lesion is considered uncommon, with a frequency of $3 \%$ of all odontogenic tumors ${ }^{22}$. In a retrospective study of 2652 maxillomandibular lesions, 127 were odontogenic tumors, with 6 cases of AOT and only 1 localized in the mandible ${ }^{23}$. In addition, AOT is also known as a "two-thirds tumor" because it has a two-thirds occurrence in the maxilla, two-thirds contain radio-opaque flakes inside the lesion and two-thirds of the affected teeth are non-erupted canines ${ }^{24}$.

This lesion is more prevalent in females in the second decade of life. In a review of 255 case reports of AOT from 2000 to 2014, the female to male ratio was $1.45: 1$ and the predominant age was $10-19$ years ${ }^{24}$. In addition, this tumor is more frequent in black african patients ${ }^{25}$ compared to caucasian patients ${ }^{26}$ and is often associated with an impacted canine ${ }^{3,4}$. The tumor described in this case report was diagnosed in a caucasian 12-years-old patient and the mandibular lateral incisor was involved in the lesion.

Regarding to radiographic aspect, AOT has three variants: follicular, extrafollicular and peripheral ${ }^{14}$. In the follicular pattern, the lesion is associated with an impacted tooth, distinct from the extrafollicular variant that is positioned above, overlapping or between roots ${ }^{15}$. The peripheral variant is the rarest and is usually located in the anterior superior gingiva ${ }^{27}$. Interestingly, in the current case report, the patient presented a mixed lesion involving a mandibular lateral incisor. The follicular pattern, as observed in this case, is responsible for $73 \%$ of central $\mathrm{AOT}^{28}$.

Macroscopically, AOT may be solid or cystic and generally shows slow growth ${ }^{10,29}$. Due to the growth profile, the detection of more extensive lesions is uncommon. However, untreated tumors can have more extensive proportions and result in facial asymmetries ${ }^{30}$. In fact, the early diagnosis of this clinical case seems to be associated with the clinical aspect regarding the slight increase in volume in the alveolar ridge.

Differential diagnosis of AOT is related to radiographic density. Indeed, the diagnosis of radiolucent lesions may include dentigerous cyst, ameloblastoma and odontogenic keratocyst while mixed lesions may include calcifying epithelial odontogenic tumor and calcifying odontogenic cyst. In this case report, CBCT had a key role in this differential diagnosis, since radiopaque flakes were not observed on panoramic radiography ${ }^{21}$.

Concerning to treatment, conservative strategies have been adopted, because the tumor is benign, generally well encapsulated and slow-growing ${ }^{31,32}$. In this case report, the lateral incisor affected by AOT was maintained for subsequent orthodontic traction. Bone resections should be indicated only in cases of larger tumors and may increase the risk of bone fractures ${ }^{33,34}$. In fact, several authors have been described favorable prognostic conditions ${ }^{9,19,35-37}$.

These findings were also observed in our case report, characterized by complete bone repair after complete removal of lesion at the 3year follow-up. In this evaluation, no signs of recurrence were detected. However, although rare tumor reccurence has been reported ${ }^{17,38,39}$. Therefore, the proservation of these patients is relevant, even if the prognosis is favorable. 


\section{CONCLUSION}

This case report showed a mandibular AOT in a 12-year-old female patient referred for orthodontic-surgical of both impacted right mandibular canine and lateral incisor. The treatment included a conservative approach, characterized by curettage of lesion and subsequent orthodontic traction of the impacted teeth. At 1 and 3-year postoperatively, followups examinations showed extensive bone repair, resolution of the tooth-retention and absence of recurrence.

\section{REFERENCES}

1. Soluk-Tekkeşin M, Wright JM. The World Health Organization classification of odontogenic lesions: a summary of the changes of the 2017 (4th) edition. Turk Patoloji Derg. 2018;34:1-18.

2. Swasdison $S$, Dhanuthai $K$, Jainkittivong $A$, Philipsen HP. Adenomatoid odontogenic tumors: an analysis of 67 cases in a Thai population. Oral Surg Oral Med Oral Pathol. Oral Radiol Endod. 2008;105:210-15.

3. More CB, Das S, Gupta S, Bhavsar K. Mandibular adenomatoid odontogenic tumor: Radiographic and pathologic correlation. J Nat Sci Biol Med. 2013;4(2):457.

4. Chrcanovic BR, Gomez RS. Adenomatoid odontogenic tumor: an updated analysis of the cases reported in the literature. J Oral Pathol Med. 2019;48:10-6.

5. Worawongvasu R, Tiensuwan M. Odontogenic tumors in Thailand: a study of 590 Thai patients. J Oral Maxillofac Surg Med Pathol. 2015;27:567-576.

6. Philipsen HP, Reichart PA. Adenomatoid odontogenic tumour: facts and figures. Oral Oncol. 1999;35:125-31.

7. de Matos FR, Nonaka, CFW, Pinto LP, de Souza LB, de Almeida Freitas R. Adenomatoid odontogenic tumor: retrospective study of 15 cases with emphasis on histopathologic features. Head Neck Pathol. 2012;6:430-37.

8. Sharma N, Passi S, Kumar VV. Adenomatoid odontogenic tumor: As an unusual mandibular manifestation. Contemp Clin Dent. 2012;3:S29.

9. Katiyar A, Gupta S, Gupta K, Pandey M. Trauma to tumor: a hunt of adenomatoid odontogenic tumor-a rare case report. Int J Clin Pediatr Dent. 2019;12:366.

10. Philipsen HP, Reichart PA, Zhang KH, Nikai H, Yu QX: Adenomatoid odontogenic tumor: biologic profile based on 499 cases. J Oral Pathol Med. 1991;20:149-58.

11. Rick GM. Adenomatoid odontogenic tumor. Oral Maxillofac Surg Clin. 2004;16: 333-54.

12. Jayasuriya PR, Rambukewella IK, Tilakaratne WM, Mendis BRRN, Lombardi T. Clinicopathological presentations of cystic and classic adenomatoid odontogenic tumors. Diagnostics. 2020;10:3.

13. Medeiros MFD, Landin FDS, Nogueira PT, Gouveia MVDC, Santos ACN, Faro TF. Tumor odontogênico adenomatoide: relato de caso. Rev Cir Traumatol Buco-maxilo-fac. 2014;14:27-32.

14. Mehta D, Madan S, Shah SP, Dewan SK. Adenomatoid odontogenic tumour of mandibular anterior region: review of literature and report of a rare case. J Craniofac Res. 2016;1:20-6.

15. Nigam S, Gupta SK, Chaturvedi KU. Adenomatoid odontogenic tumor-a rare cause of jaw swelling. Braz Dent J. 2005;16:251-53.

16. Oliveira MR, Gabrielli MAC, Gabrielli MFR, de Andrade CR, Silva BN, Pereira-Filho VA. Unusual adenomatoid odontogenic tumor. J Craniofac Surg. 2016;27:e139-41.

17. Ide F, Matsumoto N, Miyazaki Y, Kikuchi K, Kusama K. Recurrence of adenomatoid odontogenic tumor. J Oral Pathol Med. 2019; 48:96-7.

18.Zhang A, Chaw SY, Talacko AA, Besly WJ, Savage NW, Monsour PA. Central calcifying epithelial odontogenic tumour in the posterior maxilla: a case report. Aust Dent J. 2016;61:381-85.

19. Agarwal A, Giri KY, Alam S. The interrelationship of adenomatoid odontogenic tumour and dentigerous cyst: A report of a rare case and review of the literature. Case Rep Pathol. 2012;2012:358-609.

20. Vasudevan K, Kumar S, Vijayasamundeeswari SV. Adenomatoid odontogenic tumor, an uncommon tumor. Contemp Clin Dent. 2012;3:245.

21. Mosavat F, Rashtchian R, Zeini N, Goodarzi Pour D, Mohammed Charlie S, Mahdavi N. An extrafollicular adenomatoid odontogenic tumor mimicking a periapical cyst. Case Rep Radiol. 2018;2018:1-5.

22. Khot K, Vibhakar A. Mural adenomatoid odontogenic tumor in the mandible: $A$ rare case. Int J Oral Maxillofac Pathol. 2011;2:35-9.

23. Bhagwat A, Barpande SR, Bhavthankar JD, Mandale MS, Humbe J, Singh P. Odontogenic tumors: Review of 127 cases in Marathwada region of Maharashtra. J Oral Maxillofac Pathol. 2017;21:457.

24. Sethi $S$, Kumar $M$, Aggarwal $P$, Kumar $H I$, Sugandhi CD, Singh S. A case report and short review on changing trends in the site of occurrence of adenomatoid odontogenic tumor: Unravelling the past 15 years. Dent Res J. 2016;13:462.

25. Reichart PA, Philipsen HP. Odontogenic tumor facts and figures. Oral Oncol. 1998;35:125-31.

26. Handschel JG, Depprich RA, Zimmermann AC, Braunstein S, Kübler NR. Adenomatoid odontogenic tumor of the mandible: review of 
the literature and report of a rare case. Head Face Med. 2005;1:1-5.

27. Câmara PR, de Moraes SN, do Carmo ABC, Júnior AT, de Souza Azevedo R. Tumor odontogênico adenomatoide: relato de um caso clínico destacando os seus principais diagnósticos diferenciais. Rev Bras Odontol. 2016;73:348.

28. Philipsen HP, Reichart PA. Revision of the 1992-edition of the WHO histological typing of odontogenic tumours. A suggestion. J Oral Pathol Med. 2002;31:253-58.

29. Reichart PA, Philipsen HP. Odontogenic tumors and allied lesions. Quintessence Pub, London, 2004:189-97.

30. Marx RE, Stern D. Oral and maxillofacial pathology: a rationale for diagnosis and treatment. Hanover Park: Quintessence Pub, 2003:609-12.

31. Mohamed A, Singh AS, Raubenheimer EJ, Bouckaert MMR. Adenomatoid odontogenic tumour: review of the literature and an analysis of 33 cases from South Africa. Int J Oral Maxillofac Surg. 2010;39:843-46.

32. Devakalavar KN, Bali A, Chawla JPS, Pandher PK. An atypical adenomatoid odontogenic tumour in the mandible: a report of a paediatric case. Ann Pediatr Surg. 2018;14:36-8.

33. John JB, John RR. Adenomatoid odontogenic tumor associated with dentigerous cyst in posterior maxilla: A case report and review of literature. J Oral Maxillofac Pathol. 2010;14:59.

34. Han L, Downing A, Farr D, Dasgupta K, Stewart D. Adenomatoid odontogenic tumour: A rare threat to orthodontic treatment planning. J Orthod. 2019;46:259-66.

35. Philipsen HP, Reichart PA, Nikai $H$. The adenomatoid odontogenic tumour (AOT): an update. Oral Med Pathol. 1997;2:55-60.

36. Handschel JG, Depprich RA, Zimmermann AC, Braunstein S, Kübler NR. Adenomatoid odontogenic tumor of the mandible: review of the literature and report of a rare case. Head Face Med. 2005;1:1-5.

37. Al-Shimari F, Chandra S, Oda D. Adenomatoid odontogenic tumor: case series of 14 with wide range of clinical presentation. J Clin Exp Dent. 2017;9:e1315.

38. Yamamoto E, Komatsu Y, Iwai M, Kamoi H, Ito S, Kohama G. A case of recurrent adenomatoid odontogenic tumor extended to maxillary sinus. Maxillofac Prosthetics. 1985;8:125-26.

39. Chuan-Xiang Z, Yan G. Adenomatoid odontogenic tumor: a report of a rare case with recurrence. J Oral Pathol Med. 2007;36:440-43.

\section{CONFLICTS OF INTERESTS}

The authors declare no conflicts of interests.

CORRESPONDING AUTHOR

Gilson Cesar Nobre Franco

State University of Ponta Grossa,

General Carlos Cavalcanti, 4748,

ZIP Code 84030-900 Ponta Grossa, Paraná, Brazil Phone: +5542998039617

E-mail: gilsoncnf@gmail.com
Received 04/01/2021

Accepted 16/07/2021 